\title{
MI1 - derivative of maleimide inhibits cell cycle progression in tumor cells of epithelial origin
}

\author{
L. V. Garmanchuk, E. O. Denis, V. V. Nikulina, O. I. Dzhus, \\ O. V. Skachkova ${ }^{1}$, V. K. Ribalchenko, L. I. Ostapchenko
}

ESC «Institute of Biology» National Taras Shevchenko University of Kyiv 64/13, Volodymyrska Str., Kyiv, Ukraine, 01601

${ }^{1}$ National Cancer Institute

33/43, Lomonosova Str., Kyiv, Ukraine, 03022

liudmylagarmanchuk@rambler.ru

\begin{abstract}
Aim. MII is a promising maleimide derivative, which exhibits antiproliferative effect on different cells. The aim of present study was to investigate influence of MII on the cell cycle of cancer cells and its cytotoxity. Methods. The proliferative activity and viability of human cancer cell lines (colorectal adenocarcinoma - Colo-205; breast cancer-MCF-7; cervix cancer HeLa) obtained with MTT-test and cell counts were performed using a tripan blue dye. Distribution of cell cycle phases was obtained using flow cytometry method. Results. In the present study we demonstrate a detectable cytostatic effect of the maleimide derivative MII on the epithelial cell lines Colo-205, MCF-7 and HeLa. In the presence of MII the number of cells in the $G_{2} / M+S$ phases of the cell cycle dropped by 20-30\% $(p<0.05)$ relative to control. Conclusions. The results suggest that MII may be a perspective drug for antitumor therapy and perhaps deserves further study in detail.
\end{abstract}

Keywords: maleimide derivatives, cell cycle, cell culture.

Introduction. Protein kinase hyperactivity is often observed in different types of tumor cells. This activity permanently stimulates proliferative signal cascades, increasing the frequency of cells entering the mitotic phase, which is one of the major features of malignancy. Protein kinase inhibition can promote cell cycle arrest [1-4], thus preventing malignization.

Some characteristics of the chemical structure of maleimide make it a perspective cytostatic agent. By the end of the XX century, a number of maleimide derivates, such as bisindolylmaleimides, azoindolylmaleimides, and arylindolylmaleimide, were known for their antiproliferative effects [5]. The antiproliferative effects on cancer cells are produced by the products of nucleophilic substitution of a chlorine atom in the 3,4-dichloro-1H-pyrrole-2,5-dione (maleimides) with $\mathrm{N}$-nucleophiles (primary, secondary aliphatic, and aromatic ami-

(c) Institute of Molecular Biology and Genetics, NAS of Ukraine, 2013 nes). The set of maleimide derivatives for our study was synthesized at Research and Production Biochemical Center of Taras Shevchenko National University after the stage of in silico design.

The general scheme of the synthesis is shown in Fig. 1. As revealed by the results of pre-screening, the substance number 1.14 turned out to be the most potent cytostatic one, with the lowest general toxicity. This agent was classified as 1-(4-Cl-benzyl)-3-Cl-4- $\left(\mathrm{CF}_{3}\right.$-phenylamino)-1H-pirrol-2,5-dion, hereby denoted as MI1 (Fig. 2) [6]. At the in silico stage of substance molecular design, we expected that its spatial configuration would be complementary to the ATP-binding site of protein kinases. MI1 conformation resembles the ATP molecule but lacks the sites of hydrolysis and can act as a competitive inhibitor of protein kinases. The biochemical studies showed its ability to inhibit enzymes of protein kinase class, especially effective against tyrosine kinases $[6,7]$. The strong cytostatic and low cytotoxic effects of 
<smiles>[R]c1ccc(CN)cc1</smiles><smiles>[R]c1ccc(CN2C(=O)C(Cl)=C(Nc3ccc(C)cc3)C2=O)cc1</smiles><smiles>[Y]c1ccc(CN2C(=O)C(Cl)=C(Nc3ccc([R2])cc3)C2=O)cc1</smiles><smiles>C1CC(CC2CCOC2)CO1</smiles><smiles>[R2]c1ccc(CN2C(=O)C(Nc3cccc([R2])c3)=C(Sc3nc(C)c(Cl)c(Cl)c3C)C2=O)cc1</smiles><smiles>[R]c1ccc(CN2C(=O)C(Cl)=C(Cl)C2=O)cc1</smiles>

Fig. 1. General synthesis pathway of 1-(4-R-benzyl)-3-cloro-4-(R2-penylamino)-2,5-dyhidro-1N2,5-pirrolediones<smiles>O=C1C(Cl)=C(Nc2cccc(C(F)(F)F)c2)C(=O)N1Cc1ccc(Cl)cc1</smiles>

Fig. 2. Substance 1.14: 1-(4-Cl-benzyl)-3-Cl-4-( $\mathrm{CF}_{3}$-phenylamino)1H-pirrol-2,5-dion (MI1)

MI1 have been observed in tests on some epithelial derived cell lines [8]. The animal studies have confirmed a low toxic influence of MI1 on the digestive tract and reproductive system [9-11]. MI1 significantly suppresses the development of 1,2-dimethylhydrazine-induced colorectal tumors, both in prevention and in the treatment modes [12].

Therefore, the promising findings from previous studies suggest that MI1 should be explored more thoroughly. The aim of the present research was to investigate the effect of MI1 on the cell cycle progression, proliferative activity, and viability of transformed epithelium derived cells.

Materials and methods. Human epithelial derived cell lines were used to determine the cytotoxic/cytostatic MI1 effects. These were the colorectal cancer cell line Colo-205, the breast cancer line MCF-7, and the cervix cancer line $\mathrm{HeLa}$ (cell lines were kindly provided by Dr I. Goot, University of London).

Cells were incubated with MI 1 for $24 \mathrm{~h}$ under normal conditions in 96 well plates for MTT-test. Initial cell concentration was about $5 \cdot 10^{4}$ cells $/ \mathrm{ml}$ in the sample volume of $100 \mu$ l. As a culture media, we used DMEM («Sigma», USA) with $10 \%$ FBS («Sigma»), 2 mM Lglutamine, and $40 \mu \mathrm{g} / \mathrm{ml}$ gentamicin. Different concentrations of MI1 were added to cell cultures in $100 \mu$ l of media after the period of cell adaptation in normal conditions $\left(5 \% \mathrm{CO}_{2}, 100\right.$ humidity, $\left.37^{\circ} \mathrm{C}\right)$ during $4 \mathrm{~h}$. The number of living cells was determined in wells using MTT-colorymetric test and cell counts were performed using a tripan blue dye after $24 \mathrm{~h}$ incubation with MI1 [13]. The MI1 cytotoxic effect was evaluated as percent of live cells relative to control and characterized by $\mathrm{IC}_{50}$ index.

The distribution of cells in different phases of the cell cycle was assessed by flow cytometry [14]. Cells were plated in 6-well plates at the density $5 \cdot 10^{4}$ cells $/ \mathrm{ml}$ in total volume $5 \mathrm{ml}$ of complete culture medium. Cells were incubated with MI1 at densities ten times lower than the $\mathrm{IC}_{50}$ index estimated for each line by MTT-test. The cells were incubated for $48 \mathrm{~h}$ under normal conditions. The proportions of cells in different phases of the cell cycle were measured by flow cytometry with argon laser $\left(\lambda_{\text {excitation }}=488 \mu \mathrm{m}, \lambda_{\text {emission }}=585 / 40 \mu \mathrm{m}\right)(\ll$ Becton Dickinson», USA) following standard staining. The samples were analyzed with the help of the Mod Fit LT 3.0 («BDIS», USA) software.

Results and disscusion. The results of cytostatic/cytotoxic screening showed that the most susceptible to MI1 cell line was MCF-7. The $\mathrm{IC}_{50}$ index for MCF-7 was $0.21 \mathrm{mM}$ (Fig. 3, $B$ ), while for HeLa and Colo-205 the indices were 0.43 and $0.63 \mathrm{mM}$, respectively (Fig. 3, $A, C$ ). 

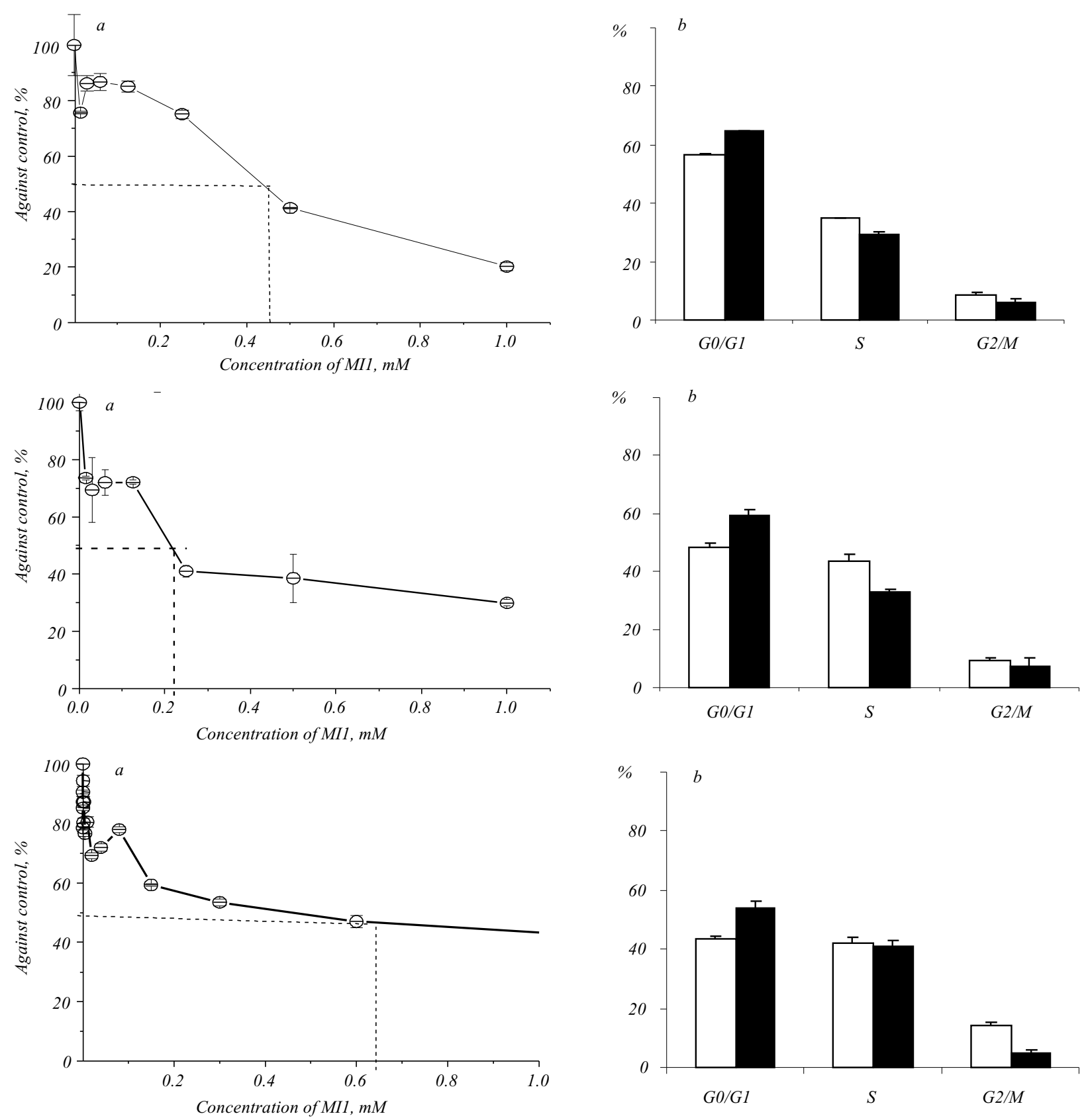

Fig. 3. Results of cytostatic/cytotoxic screening of MI1 effect for HeLa $\left(A, \mathrm{IC}_{50}=0.43 \mathrm{mM}\right), \operatorname{MCF}-7\left(B, \mathrm{IC}_{50}=0.21 \mathrm{mM}\right)$, Colo-205 $\left(C, \mathrm{IC}_{50}=0.63 \mathrm{mM}\right)$ : MTT-test $(a)$ and flow cytometry $(b)$ data demonstrate cell cycle suppression (b: 1 - control; 2 - MI1)

Our results confirm earlier evidence indicating low cytotoxity of MI1 for cell cultures and reveal its antiproliferative effect. For that reason each cell line was incubated at corresponding MI1 concentration that was ten times lower than the $\mathrm{IC}_{50}$ index. The concentrations used were as follows: for HeLa $-0.04 \mathrm{mM}$, for MCF-7 $0.02 \mathrm{mM}$, and for Colo-205- $0.06 \mathrm{mM}$. The ratio of live to dead cells was calculated in hemocytometer with trypan blue staining. The Colo-205 cell line was the most susceptible to MI1 toxic influence and demonstrated $17 \pm 1.5 \%$ dead cells (Table), while HeLa and MCF-7 cells showed higher survival rates (more than $90 \%$ ) relative to control.

Thus, only Colo-205 cells demonstrated enchanced susceptibility to toxic effect at subtoxic MI1 concentrations. 
Cells viability under the MII influence (cell counts were performed using a tripan blue dye)

\begin{tabular}{|c|c|c|c|}
\hline \multirow{2}{*}{ Cells } & \multicolumn{3}{|c|}{ Cells, \% } \\
\hline & HeLa & MCF-7 & Colo-205 \\
\hline \multicolumn{4}{|c|}{ Control } \\
\hline live & $92.9 \pm 3.2$ & $94.5 \pm 3.9$ & $93.6 \pm 0.9$ \\
\hline dead & $8.5 \pm 2.5$ & $6.9 \pm 3.2$ & $5.8 \pm 3.2$ \\
\hline \multicolumn{4}{|c|}{ Concentration of MII, $\mathrm{mM}$} \\
\hline & 0.04 & 0.02 & 0.06 \\
\hline live & $89.5 \pm 2.5$ & $90.2 \pm 3.7$ & $82.8 \pm 5.4$ \\
\hline dead & $12.6 \pm 3.8$ & $11.4 \pm 1.9$ & $17 \pm 1.5^{*}$ \\
\hline
\end{tabular}

$* \mathrm{p}<0.05$, against control.

The pool of proliferating cells decreased in all the lines tested (Fig. 3). The proportion of total cell population in $\mathrm{G} 2 / \mathrm{M}+\mathrm{S}$ phases for Hela was $45.6 \pm 2.5 \%$ in control and $35.4 \pm 0.6 \%$ with MI1; for MCF-7 $-52.4 \pm$ $\pm 0.7 \%$ in control and $39.4 \pm 0.7 \%$ in the test; for Colo-205 it was $-56.7 \pm 0.9 \%$ and $45.4 \pm 0.8 \%$, respectively. The fraction of cell population in $\mathrm{G} 1 / \mathrm{G} 0$ phases increased, thus, revealing a clear cytostatic effect of the tested substance. The described MI1cytostatic effects were probably based on the previously observed tyrosine kinase inhibitory activity.

Conclusions. 1. 1-(4-Cl-benzyl)-3-Cl-4- $\left(\mathrm{CF}_{3}\right.$-phenylamino)-1H-pirrol-2,5-dion is demonstrates a moderate toxic effect on epithelial derived tumor cells. $\mathrm{IC}_{50}$ index is: for HeLa $-0.43 \mathrm{mM}$, for MCF-7 $-0.21 \mathrm{mM}$, for Colo-205 - $0.63 \mathrm{mM}$.

2. Cell survival at subtoxic concentrations MI1 $\left(\mathrm{IC}_{50}\right)$ did not significantly differ from control for HeLa and MCF-7, and was lower for Colo-205 (82.8 $\pm 5.4 \%$ versus $93.6 \pm 0.9 \%$ ).

3. Flow cytometry analysis demonstrated that in the presence of MI1 cells tend to enter the G1/G0 phase. The proportion of non-dividing cells increased by 20 $30 \%(\mathrm{p}<0.05)$.

Л. В. Гарманчук, С. О. Деніс, В. В. Нікуліна, О. І. Джус,

О. В.Скачкова, В. К. Рибальченко, Л. І.Остапченко

MI1 - похідне малеїміду пригнічує прогресію клітинного циклу у пухлинних клітинах епітеліального походження

Резюме

Мета. Для похідного малеїміду МІ1 виявлено пригнічення проліферачії клітин, опосередковане інгібуванням тирозинкіназ. Мета да- ної роботи полягала в поглибленому вивченні впливу МI1 на перебіг клітинного ичиклу у пухлиннх клітинах, а також на їхню життездатність. Методи. Проліферативну активність та життездатність клітинних ліній раку людини (колоректальна аденокариинома - Colo-205; рак молочної залози - MCF-7; рак шийки матки HeLa) визначали за допомогою MTT-тесту та рутинного підрахунку клітин, забарвлених трипановим синім. Розподіл клітинної популяиії за фазами клітинного циклу здійснювали методом проточної иитофлуориметрії. Результати. Показано иитостатичну дію похідного малеїміду МI1 щодо клітинних ліній епітеліального походження Colo-205, MCF-7 i HeLa. Taк, кількість клітин у фазах $G 2 / M+S$ клітинного изиклу зменшувалася приблизно у 1,2-1,3 разу $(p<0.05)$ для всіх клітинних ліній за впливу малеїміду порівняно з контролем. Висновки. МI1 можна розглядати як перспективну протипухлинну сполуку, щзо потребує подальшого дослідження.

Ключові слова: похідні малеїміду, клітинний изикл, клітинні культури.

Л. В. Гарманчук, Е. О. Денис, В. В. Никулина, Е. И. Джус,

О. В.Скачкова, В. К. Рыъбальченко, Л. И.Остапченко

MI1 - производное малеимида подавляет прогрессию клеточного цикла в опухолевых клетках эпителиального происхождения

Резюме

Цель. Для производного малеимида МI1 обнаружено замедление пролиферации клеток, опосредованное ингибированием тирозинкиназ. Цель данной работы состояла в углубленном изучении влияния MII на прохождение клеточного иикла в раковых клетках, а также на их выживаемость. Методы. Пролиферативную активность и выжсиваемость клеточных линий рака человека (колоректальная аденокариинома - Colo-205; рак молочной железы - MCF-7; рак шейки матки - HeLa) определяли с помошью MTT-теста и рутинного подсчета клеток, окрашенных трипановым синим. Распределение клеточной популяции по фазам клеточного иикла производили методом проточной ичитофлуориметрии. Результаты. Показано иитостатическое и антипролиферативное действие производного малеимида MI1 на клеточные линии эпителиального происхождения Colo-205, MCF-7 и HeLa. Так, количество клеток в фазах $G 2 / M+S$ клеточного ичикла уменьшалось в $1,2-1,3$ раза $(p<0.05)$ для всех линий по сравнению с конт- 
ролем. Выводы. Производное малеимида МI1 можно рассматривать как перспективное противоопухолевое соединение, что требует дальнейших исследований.

Ключевые слова: производные малеимида, клеточный ичил, клеточные культуры.

\section{REFERENCES}

1. Blume-Jensen P., Hunter T. Oncogenic kinase signalling // Nature.-2001.-411, N 6835.-P. 355-365.

2. Hanahan D., Weinberg R. A. Hallmarks of cancer: The next generation // Cell.-2011.-144, N 5.-P. 646-674.

3. Novak K. K. Protein kinase inhibitors in cancer treatment: mixing and matching?: Highlights of the Keystone Symp. on Protein Kinases and Cancer (February 24-29, 2004; Lake Tahoe, California) // Med. Gen. Med.-2004.-6, N 2.-P. 25.

4. Perona $R$. Cell signalling: growth factors and tyrosine kinase receptors // Clin. Transl. Oncol.-2006.-8, N 2.-P. 77-82.

5. Hers I., Tavare J. M., Denton R. M. The protein kinase C inhibitors bisindolylmaleimide I (GF 109203X) and IX (Ro318220 ) are potent inhibitors of glycogen kinase-3 activity // FEBS Lett. -1999.-460, N 3.-P. 433-436.

6. Pat. 22204 Ukraine. Compound of 1,4-disubstituted 5-amino-1,2-dihydropyrrole-3-one having anticancer activity / G. G. Dubinina, Yu. M. Volovenko.-U200601855; Appl. 21. 02.2006. Publ. 25.04.2007.

7. Jaye M. C., Krawiec J. A., Campobasso N., Smallwood A., Qiu C., Lu Q., Kerrigan J. J., De Los Frailes Alvaro M., Laffitte B., Liu W. S., Marino J. P. Jr., Meyer C. R., Nichols J. A., Parks D. J., Perez P., Sarov-Blat L., Seepersaud S. D., Steplewski K. M., Thompson S. K., Wang P., Watson M. A., Webb C. L., Haigh D., Caravella J. A., Macphee C. H., Wil- lson T. M., Collins J. L. Discovery of substituted maleimids as liver $\mathrm{X}$ receptor agonists and determination of a ligand- bound crystal structure // J. Med. Chem.-2005.-48, N 17.- P. 5419-5422.
8. Yablonska S., Filinska O., Ostrovska G. Antiproliferative properties and low hepatotoxicity of new cytostatic malemide derivate $/ / 33^{\text {rd }}$ FEBS Congr. and $11^{\text {th }}$ IUBMB Conf. on Biochemistry of cell regulation (June 28-July 3, 2008, Athens, Greese).-Athens, 2008.-P. 348.

9. Lynchac O. V., Charchuk I. V., Karpezo N. O., Ostrovska G. V., Rybalchenko $V$. K. Morpho-functional state of the organs of gastro-intestinal tract under the maleimide derivate action during one month // Modern Problems of Toxicology.-2011.-N 1-2.P. 52-55.

10.Charchuk I. V., Karpezo N. O., Ostrovska G. V., Rybalchenko T. V., Lynchac O. V., Cyvinska S. M., Lenchuk O. P., Rybalchenko V. $K$. The morpho-functional chenges in the rat's testes under the influence of the new antineoplastic medcine derivate of maleimide // Modern Problems of Toxicology.-2008.-N 1.-P. 61-64.

11. Lynchak O. Ostrovska G., Burlaka A. State of colon mucosal under the effects of new protein-tyrosine kinases inhibitor maleimide derivate // Gut "GASTRO 2010-18 ${ }^{\text {th }}$ UEGW: Barcelona».-2010.-58 (Suppl II).-P. A133.

12. Lynchak O., Ostrovska G., Rybalchenko V. K. Effects of new maleimide derivate on the 1,2-dimethylhydrazine-induced colon carcinogenesis in rats // Gut «GASTRO 2009 UEGW/ WCOG, London».-2009.-58 (Suppl. II).-P. A334.

13. Mosmann T. Rapid colorimetric assay for cellular growth and survival: application to proliferation and cytotoxicity assays // $\mathrm{J}$. Immunol. Methods.-1983.-65, N 1-2.-P. 55-63.

14. Nicoletti I. Migliorati G., Pagliacci M. C., Grignani F., Riccardi $C$. A rapid and simple method for measuring thymocyte apoptosis by propidium iodide staining and flow cytometry // J. Immunol. Methods.-1991.-139, N 2.-P. 271-279.

Received 01.12.12 